\title{
O homem ama ocultar-se
}

\author{
The man loves to hide himself
}

Francisco Bracons Felizol Marques*

Recebido em: 10/2013

Aprovado em: 10/2015

\begin{abstract}
Resumo: Hadot distingue duas atitudes perante a Natureza: a órfica de respeitar e velar os seus segredos; a prometaica de forçar a Natureza a revelá-los. Já Girard, identifica duas naturezas humanas, o mimetismo e o mecanismo do bode expiatório, ocultadas pela mentira romântica $e$ pelo pensamento sacrificial. Defende-se aqui: a pensar a Natureza, o homem reflecte; ao espelho, pensa também sua natureza; as posturas órfica e prometaica são também posturas perante a natureza humana, especialmente a do mecanismo. Desvela-se então Hadot com Girard. A atitude órfica, veladora dos segredos da Natureza, vela, esconde o natural, mentiroso e violento mecanismo. Este, na base de toda a cultura, é, com sua temporalidade cíclica ou sacrificial, militantemente defendido pela tradição sacrificial pagã. $O$ retorno do sacrificial, com consequências catastróficas, para Girard, no séc.XX, será ideia retomada no período romântico $e$ continuada por Nietzsche e Heidegger. A atitude prometaica, desveladora impudica dos segredos da Natureza, tem seu fulcro na revelação cristã do mecanismo, impositora da inocência da vítima e da linearidade temporal. Assim, para Girard, libertar o homem da culpa, impõe a causa, impulsiona o progresso; até também este, feito "objecto expiatório" se preverter na ineficaz e perigosa sacrificialidade do capitalismo actual.
\end{abstract}

Palavras-chave: Hadot, Girard, natureza, sacrifício, bode expiatório

Abstract: Hadot distinguishes two attitudes towards nature: the orphic that respects and veils Nature secrets and Promethean attitude that forces Nature to reveal them. Girard,

* Doutorando em filosofia da Universidade de Lisboa

Problemata: R. Intern. Fil. v.6, n. 3(2015), p 283-319 ISSN 2236-8612 doi:HTTP://dx.doi.org/10.7443/problemata.v6i3.17097 
identifies two human natures, the mimetic nature and the scapegoat's mechanism, hidden by the romantic lie and the sacrificial thought. Here, we argue that: thinking on Nature, man reflects; in the mirror, he also thinks its nature; orphic and Promethean attitudes are also attitudes towards human nature, especially the scapegoat mechanism. Here we unveil Hadot with Girard. The orphic attitude hides the natural liar and violent mechanism on the basis of all culture, is, with his cyclical or sacrificial temporality, militantly defended by sacrificial pagan tradition. The return of the sacrificial, with catastrophic consequences for Girard in the XX century, will be a renewal idea in Romantic period, continued by Nietzsche and Heidegger. Promethean attitude, shameless oriented to uncover nature's secrets, has its core in the Christian revelation of the mechanism, that imposes the innocence of the victim and the temporal linearity. Thus, for Girard, freeing up man from guilt imposes the cause and drives progress until also this "scape object" is ineffective and dangerous in the pervert sacrificiality of today's capitalism.

Keywords: Hadot, Girard, nature, sacrifice, scapegoat

Não pela dificuldade, mas pela peculiaridade da linguagem e dos conceitos utilizados por René Girard, pedimos aos leitores não familiarizados com o seu pensamento a leitura prévia do anexo no fim deste trabalho que tenta expor resumidamente as suas principais teses.

\section{As duas naturezas do homem nas formas de encarar a Natureza}

Pode-se sem perigo de abuso, afirmar que Réné Girard pretende ter desvelado duas naturezas humanas na base de todo o fenómeno humano. Primeiro, a do homem considerado individualmente (que nunca deixa de implicar efeitos colectivos), a natureza mimética do seu desejo; depois a natureza sacrificial e expiatória de todo o tipo de comunidades humanas (que não deixa também de estar individualmente presente a expulsar demónios interiores). Ambas as naturezas, o homem ama negá-las, ocultá-las através da mentira romântica e do pensamento sacrificial; ambas as naturezas amam ocultar-se, se se quiser parodiar o conhecido fragmento de Heraclito. A partir da segunda tese de Girard, se aceitarmos a discutível noção de cultura como oposta à Natureza, estamos autorizados a afirmar que a cultura não só assenta na "segunda" naturalidade

Problemata: R. Intern. Fil. v.6, n. 3(2015), p 283-319 ISSN 2236-8612 
humana (no bode expiatório, na forma "natural" do homem socializar, garantir a sociedade) como controla, canaliza, aproveita a "primeira" naturalidade humana tendencialmente mimética e violenta. Já a terceira tese de Girard, a revelação cristã da segunda natureza oculta, implica também indirectamente a revelação da primeira.

Distinga-se desde já a Natureza (entendida como mundo físico material) das naturezas mimética e sacrificial (ou expiatória) das comunidades humanas. A natureza mimética do homem $^{1}$ parece em Girard aproximar-se daquela noção tradicional de Natureza como imutável. Esta natureza mimética, presente no mecanismo do bode expiatório (é ela que garante a unanimidade de todos contra um), prossegue pelos nossos comportamentos pós-revelação onde o mecanismo sobrevive adulterado: está sempre presente um modelo a imitar, é inamovível da equação humana. Mas não é aí uma constante, é uma variável. A intensidade da sua presença e dos seus efeitos não são imutáveis dependendo da distância do modelo a imitar. Já a outra natureza, a do bode expiatório, pode concordar com a abordagem historicista da natureza, segundo a qual é da natureza humana transformar a sua própria natureza. Sendo assim, mesmo a "natural" hominização é uma progressiva transformação da natureza do homem, constituindo o mecanismo do bode expiatório e sua repetição ritual um processo histórico-natural da espécie humana. Girard invoca Konrad Lorenz (Das sogenannt Böse, 1974) onde os animais "superiores" dispõem dum outro "mecanismo" de autopreservação da espécie. O duelo entre dois machos embriagados pelo cio das fêmeas raramente acaba em morte. No último momento, o combate está decido e o mecanismo intervém: perante a oportunidade de dar o golpe final no adversário, o vencedor recua. À progressiva falta deste natural mecanismo, o processo de hominização progrediu a outro natural mecanismo para preservar a espécie humana, o do bode expiatório (GIRARD, 1972, p.324). É por isto que Girard só pode responder afirmativamente à reflexão de Hadot acerca de uma possível continuidade entre os ritos humanos e os ritos da natureza, de uma pré-inscrição natural da arte, da religião, do mito e do rito (HADOT, p.90). A proposta de Aristóteles, de que a natureza, encontrando modelo de sucesso, o promove, concorda com a biologia actual (HADOT, p.216) e com Girard. 
Para se salvar da auto-destruição, controlar a natureza mimética e violenta da nossa espécie, desenvolveu-se uma natureza mentirosa assente na culpabilidade do inocente. $\mathrm{O}$ mecanismo, passo na hominização, modo de controlar os efeitos devastadores da nossa natureza mimética, permitiu que o homem desenvolvesse e preservasse a sua sociabilidade, permitiu ao homem ser homem. É revelador que Girard chame mecanismo ao processo desencadeador do bode expiatório porque, na sua visão, este é o primeiro artefacto humano, o primeiro símbolo (GIRARD, 2004, p.157), a partir do qual o homem começará a se distinguir efectivamente das outras espécies, através de inúmeras e cíclicas repetições miméticas do mesmo (a primeira natureza não é descartável, repetimos) e criará todas as instituições e artefactos, toda a cultura. A revelação cristã, o comprometer, ainda sem destruir totalmente, o mecanismo, é outro passo na hominização (GIRARD, 2007, p.212). Desta vez, é uma ameaçadora oportunidade de, desmascarando a nossa natureza mentirosa, domarmos a nossa natureza ameaçadoramente mimética. A verdade, a revelação cristã, a revelação da natureza mentirosa, pretende ser outro remédio ou fármaco natural. Esta aceleração do tempo (novamente a perspectiva histórica da natureza), substituindo a sacrificial progressão espiralar pela linearidade cristã, pode revelar-se ameaça ou reconciliação. Se a "natureza" que Moscovici (p.48) concede é a de um estado onde relativamente a outras espécies não tínhamos vantagens (Hadot rotularia esta atitude, desejosa de controlar natureza não controlada de prometaica) para outro estado pejado de vantagens culturais (divisão de trabalho, instituições, língua e símbolos), esta saída, progressiva, é, para Girard, obra do mecanismo, acelerada pela sua posterior deterioração / revelação. Veja-se como a plasticidade da teoria girardiana se adapta a duas perspectivas contrárias: quando Girard insiste no mecanismo como o passo onde o homem se liberta da animalidade, parece incluir-se nessa visão estática da natureza criticada por Moscovici. Mas se o mecanismo se serve do mimetismo, em sua unanimidade contra um, consolidadora da unidade, para contrariar o seu desenlace natural, faz do mecanismo uma natural artificialidade dentro da natureza, concordando o mimetismo com o modelo da natureza como penúltima cultura face à (última) cultura. Quando para Girard não é possível identificar o momento onde o próprio mecanismo, o símbolo, fez a sua aparição, pois é até processo já 
em germe nos animais ${ }^{2}$, facilmente esta visão se pode encaixar na interpretação preferida de Moscovici onde a noção tida usualmente por natural é a penúltima camada cultural, a penúltima relação do homem com a natureza. Esta, já ultrapassada, é agora tida como original e genuína em oposição à actual superfície cultural tida como anti-natural ${ }^{3}$. Por um lado, esta mesma visão serve de perceber como o mecanismo sacrificial continua entre nós dois mil anos após a revelação: esta sucessão de naturezas (i)maculadas, maculadas em catadupa, todas com uma natureza (i)maculada anterior está muito perto do círculo sacrificial que termina e recomeça como novo bode expiatório. Por outro lado, esta visão historicista da Natureza garante naturalidade (apesar da intervenção divina) à revelação, para Girard, causa de toda a ciência e todo o progresso material(GIRARD, 1994, p.154).

\section{O véu de Isís vela uma natureza sacrificial}

A obra de Pierre Hadot, $O$ véu de Ísis, narra, a partir da comprometida tradução do fragmento $n^{\circ} 123$ de Heraclito, «A natureza ama ocultar-se», a história das duas comprometidas atitudes, prometaica e órfica, de desvelamento da Natureza ${ }^{4}$. Não será "natural" que a atitude do homem perante a Natureza reflicta a natureza humana? Não será "natural" que este humano desvelar da Natureza seja (ou seja também) um desvelar da natureza humana? Se assim for, e se a nossa interpretação da teoria Girardiana aplicada ao problema da Natureza estiver correcta, esta epopeia desveladora será um desvelar da natureza humana como essencialmente mimética e expiatória. Imediatamente se pode reparar na proximidade entre o sagrado, esse misterium tremendum, essa violência que, para Girard, se oculta e deve manter afastada, e essa Natureza que se ama ocultar de Hadot. Também se pode reparar na proximidade entre o Véu de Ísis, a ocultação da Natureza, e essa ocultação do mecanismo em Girard, da nossa natureza sacrificial (e do mimetismo na mentira romântica) que, revelada, resultou nesse progresso material, igualizador, anti-natural, que os órficos guardiões do véu tendem a repudiar. Justifica-se a atitude positiva de Girard em relação à revelação, ao despir do véu, porque no seu pensamento o revelado não é a Natureza como verdade, mas a natureza humana essencialmente mentirosa. 
A escandalosa relação entre sexo, violência e morte, que Hadot (pp.32-33) faz a biologia confirmar na morte como condição de vida e evolução ${ }^{5}$, é ideia já antes tratada por Bataille (Le Erotisme, 1957) em suas implicações antropológicas, e é ideia reforçada por Girard onde a morte da vítima expiatória é condição de socialização, culturação, vida. $\mathrm{O}$ mecanismo, a morte colectiva da vítima expiatória garante a regeneração, a continuação da sociedade. O mecanismo, essa natureza que é mentira, violência e morte é o que suscita e ressuscita, o que mantém a sociedade pré-revelação. Aliás essa Natureza racionalizada de Aristóteles que não joga aos dados, que nada desperdiça, realocando como óptima despenseira (se quisermos já ver aqui o seu posterior aproveitamento escolástico), abundâncias e carências (HADOT, p.456) terá necessariamente de incluir processo ou mentalidade sacrificial de sacrificar a parte pelo todo ${ }^{7}$. Onde Hadot trata divinização da Natureza propriamente dita, Girard admitiria a deificação, como Natureza, da natural morte colectiva, da natural mentira, comum a todas as divindades. O esquema a partir do qual Hadot explica a deificação da physis $(\mathrm{pp} .38,46)^{8}$ vale na precisão para a posterior deificação do bode expiatório: partindo de physis processo (Girard diria união de todos contra um, morto colectivamente) na aparição das coisas (Girard diria fundação da sociedade), personifica-se e depois diviniza-se na physis (Girard diria na vítima divinizada) o poder (Girard diria o mecanismo unificador) que produz esse processo (união e efectiva refundação cultural). A Natureza como deusa em Plínio no século I ac, essa intelectualização que continua nos hinos à Natureza no século II, não escapa de ser também bode expiatório divinizado. Aliás, mesmo noutros registos afastados de Girard, ela é uma recuperação ou sobre-ocultação mais ou menos consciente, de anteriores divindades do Médio Oriente e Egipto com raízes neolíticas e função arquétipa de grande mãe ${ }^{9}$.

Não se estranhe então que a continuidade entre natureza e cultura, que gostamos de contrapor para melhor pensar, se prolongue nessa continuidade entre o pensamento mítico ou sacrificial e o pensamento dito racional, simplificação de melhor pensar também. Não pode surpreender a qualquer antropólogo ou filósofo da religião que, na senda das anteriores cosmogonias pre-socráticas, heroicas e mesmo orientais, o Timeu, relato de origem, todo ele esforço de desvelar o universo, se situe em ambiente de festa, logo sacrifício religioso, logo relato mítico de 
fundação, neste caso de Atenas, integrando a origem humana na mundana (HADOT, pp.203,204). E também não surpreende que no Timeu a narrativa da poiesis do Cosmos («esse deus que acaba de nascer em nosso discurso» em Crítias, 106a) ser ela mesmo, conscientemente, uma criação, uma imitação, uma poiesis discursiva, poema de imitar o grande poema (HADOT, pp.176,230). Esta oferenda poética que tanto entusiasma Hadot está no âmago da teoria girardiana. Todo o mito tem muito de rito, de re-presentação (e assim convocação) ou repetição mimética da poiesis fundadora do universo, repetição do acto fundador. Para além da óbvia presença da natureza mimética, temos também a presença da natureza sacrificial camufladora da morte fundadora em Platão. Este Platão, praticante da boa e mítica imitação (do modelo externo), tem paradoxalmente, mas coerentemente com a mentalidade sacrificial, uma visceral desconfiança da imitação próxima e assim perigosa. Para lá de todo o reprovatório moral, a imitação alicerça a sua crítica aos poetas heroicos e trágicos. Na República é mesmo descrita como potenciadora do conflito, semente da desordem da crise mimética onde os homens se começam a assemelhar (GIRARD, 2004, p.65) ${ }^{10}$. Na tragédia, no mimético e violento apagamento das diferenças, Platão vê o ameaçar da cidade em seus fundamentos, pressente a semi-revelação do mecanismo expiatório (GIRARD, 1972, p.441) ${ }^{11}$. O seu remédio contra este perigoso mimetismo, contra esta semi-revelação sacrificial, contra este veneno? Não pode deixar de ser mimético, violento e sacrificial. Expulse-se Sófocles com seu expulsado Édipo, façase também dele pharmakos (GIRARD, 1972, pp.437,438). Que esse bode expiatório é universal, veja-se como Platão dá o mesmo remédio aos venenosos sofistas. Como Derrida mostra em La Pharmacie de Platon (1968) o pharmakon platónico tanto é veneno para descrever a sofística como remédio para descrever a boa filosofia socrática, muito próximo do veneno / remédio que era o pharmakos humano, bode expiatório regular e ritualmente usado em Atenas (GIRARD, 1972, p.442). Para Derrida, há já em Platão um esforço de negar, de diferenciar algo que a palavra pharmakon toma por único ${ }^{12}$, para Girard, evocador daqueles gémeos combatentes mais indiferenciados quanto mais reivindicam suas diferenças (GIRARD, 1972, p.443). Mas volte-se a Hadot e ao Timeu; este esforço mimético, violento e perseguidor de Platão confirma que, dado o cunho ritual, poiético, do Timeu, «o papel do filósofo é imitar» 
(HADOT, p.230). Todo esse discurso mítico da criação, com consequentes reimitações neoplatónicas, sublinhado por Hadot, confirma o papel conscientemente camuflador de Platão, na visão de Girard. O mito de Platão é ritual camuflador, a repetir, a imitar. Até a dar remédio aos que não seguem a boa imitação, mítica e ritual, Platão imita e repete. De Platão não querer pensar a violência religiosa nem a guerra, de temer o seu poder sugestivo, mimético, contaminante, imita e repete o mecanismo expiatório, expulsa os poetas da sua cidade GIRARD, 2004, pp. 257,258$)^{13}$.

\section{A ciclicidade veladora órfica}

Para Girard, uma sociedade entra em desagregação de todos contra todos, resolvida no mecanismo de todos contra um, exactamente quando as barreiras, mitos e interditos, mais as canalizações de escoamento da violência, os ritos sacrificiais, deixam de funcionar. Cada cultura, desde a sua fundação em bode expiatório, assenta principalmente na negatividade dos interditos a conter a violência, e numa poiética e periódica repetição simbólica desse mesmo acto em rito ou sacrifício ${ }^{14}$ até este acto perder a sua eficácia, perder o efeito de catarse expulsador da violência, exteriorizadora do sagrado que pretende provocar. A história da humanidade até Cristo é então uma sucessão de bodes expiatórios, com uma sucessão de vítimas sacrificiais, que os imitam, entre eles. Facilmente a teoria girardiana reconhece a visão cíclica sacrificial na antiga concepção da Natureza, onde o cosmos constituído infinitas vezes se extingue para infinitas vezes se reconstituir ${ }^{15}$. Se falamos em eterno retorno, falamos em repetição, forma de imitação. Mesmo se nos abstrairmos do bode expiatório girardiano, podemos concluir que a respiração periódica da Natureza, periodicamente renascida na Primavera, tem já consciente imitação religiosa por exemplo nos ritos de vegetação ou de solstício.

Siga-se àquela percepção da função integradora do mito (já tratada por Simmel (1982, p.662) e abundantemente tratada pela psicanálise, mesmo quando em forma de conto) que Hadot detecta na atitude órfica (p.63). Hadot atribui aos filósofos da tradição platónico-estoica uma dupla postura (já aliás em Platão) onde Girard reconheceria uma ocultação consciente do 
mecanismo: reconhecendo a utilidade educadora (pacificadora, podemos abusar) dos mitos e ritos para o povo, têm-nos como velada revelação da Natureza, diferentes representações de Deus que cabe ao filósofo, em exegese alegórica, física e moral, desvelar (HADOT, p. 62). Os deuses ocultam-se, nas suas descrições míticas, nas suas re-presentações rituais. Podem os estoicos igualar a Natureza a Deus fazendo dos deuses processos naturais, podem os neoplatónicos (numa atitude de tímida exteriorização) remeter a Natureza a inferiores formas corpóreas e visíveis da una divindade, dado o atrito atmosférico de sua descida à matéria (HADOT pp.76,77). Ambas as soluções são para a perspectiva girardiana uma consciencialização dessa natureza mentirosa, uma semi-revelação ou intuição do mecanismo oculto. Em ambiente neoplatónico, a consciência da ocultação está tanto na teologia negativa de "não descrever" a tão luminosa que ofuscadora divindade, como no mito de "reescrever" as divindades involucradas em corpos (HADOT p.75) ${ }^{16}$. Em Porfírio, além dessa Natureza envolta em formas sensíveis, estátuas e mitos, está mesmo já a clara consciência do ritual religioso como mimetismo da actividade divina. E quando advoga que a revelação alegórica destes invólucros se deve prudentemente velar ao vulgo profano (respeitando a vontade de corpórea ocultação dessas potencias incorpóreas), podemos falar com segurança de uma perspectiva conscientemente sacrificial. Quando se percebe a natureza mentirosa mas útil dos mitos, das estátuas a adorar e dos ritos miméticos, a mentira é definitivamente consciente. Não espanta então que, para além dessas divindades inferiores, também os demónios precisem de se ocultar (HADOT p.90), subidos por Jâmblico, a guardiões dos segredos da Natureza. Para Girard, é precisamente o segredo da natureza sacrificial e expiatória, o mecanismo oculto, que conserva todas as instituições culturais, o universo pré-revelação (e que luta por sobreviver depois da revelação) materializado em Satã e nos senhores deste mundo, que conserva. O interdito de levantar o véu à Natureza, de o revelar aos profanos, é o interdito de revelar o mecanismo, a natureza das sociedades humanas. É curioso como o avanço do cristianismo revelador do mecanismo, apontado à inocência da vítima expiatória, vai reforçar a consciencialização do mito (e suas re-presentações rituais) pio-mentiroso no paganismo. O paganismo que toma consciência da ameaça cristã, chamemos-lhe o paganismo militante, vai organizar-se contra o seu avanço, vai, 
coerentemente com a teoria mimética, imitar o cristianismo, à maneira dos gémeos em combate ${ }^{17}$. O paganismo militante (que deve o seu aparecer à aparição do cristianismo) faz da adulterada mas dominante interpretação do aforismo de Heraclito, da natureza que ama ocultar-se, sua defesa: o mito e o culto dos deuses são proveitosa ocultação da natureza, conservadora do universo (HADOT pp.91,96,97) ${ }^{18}$. O utilitarismo da ocultação mítica da natureza, já presente em Porfírio, segue assim em Jâmblico, Juliano e Proclo, e, força do cristianismo, rival mimético a combater, faz mesmo a Natureza deixar as camadas inferiores da teologia. Encare-se então o véu dessa Isis-natureza: face à imp(r)udência desveladora cristã (destruidora de mitos, estátuas e ritos sacrificiais, universalizadora e assim arrasadora e igualizadora das, em modo e espaço, diferenciadas divindades pagãs), a p(r)udência veladora, conservadora, pagã. A atitude órfica é pré-cristã, já se preocupa com o violentar da Natureza antes da chegada do cristianismo; mas reforça-se e toma decididamente consciência da mentira com o cristianismo. O aviso pré-cristão de Cícero (HADOT p.52) ${ }^{19}$, antecedendo Goethe, de que forçar a observação da Natureza faz ocultar o fenómeno, concorda com a perspectiva de Girard que revelar a natureza sacrificial a perturba definitivamente. Revelar, trazer à luz é destruir. O Cristo Prometeu de Girard arrancou os homens de seu mecanismo, natureza ou divindades sacrificiais. Como Hadot vê claramente, o segredo da Natureza opõe um visível fenomenal a um invisível que nele se esconde (p.53) - como a nossa natureza sacrificial, como o mecanismo do bode expiatório, como até a interpretação, ao lado, que Hadot dá aos múltiplos seios da deusa (pp.257,258), velando com a teoria dos múltiplos adornos a sua faceta de mãe nutridora, ciclicamente regeneradora e conservadora.

\section{A atitude Prometaica e a revelação do mecanismo}

Para Lenoble, Aristóteles recupera essa Natureza, até aí "necessidade contra a qual somos impotentes" para uma visão da natureza como ordem, e daí modelo de ordem, lei e segurança face ao acaso (pp.184,185). Para Girard, não deixará este interiorizar ordenador da Natureza de ser sacrificial também pois continua a haver um fora, um exterior ameaçador, mesmo 
que agora fora da natural ordem: o lugar da desordem bárbara. No esquema universal de cá dentro lei, ordem e segurança face ao aí, o ameaçador, desconhecido, mutável, tendencialmente desordenado, que é necessário exteriorizar, transcendentalizar, expiar, colocar para lá, é quase indiferente em que polo colocar a Natureza. Se agora uma Natureza, criada por intelectualizado e descarnado primeiro motor se rege por leis a um fim (HADOT, p.186, outra grande âncora de segurança, essa causa final aristotélica), se agora a Natureza ordenada, pacificada, domesticada, é modelo a pedir imitação, pouco diferirá dos efeitos práticos, pacificadores e sacrificiais conseguidos com as divindades pagãs caótico-naturais. $\mathrm{Na}$ perspectiva girardiana, a demarcada intelectualização do Deus aristotélico tem a vantagem de substituir causas por culpas, mas não previne o refluxo da culpa e assim do mecanismo; para isso é preciso que se revele a inocência do carregador de culpas, do bode expiatório, que se revele a mentira sobre a qual todo o humano se funda. Mas tem a desvantagem de, sendo agora a Natureza modelo a imitar, se ter ainda modelo cíclico, quer dizer, novamente sacrificial. E tem ainda a clara desvantagem de, estando agora esta Natureza de ordem com fim feita lugar onde agora o homem habita, lhe comprometer a exteriorização como modelo a imitar. Apresentando uma perigosa proximidade com o homem, facilmente também ela, ou sua personificação, cairá a modelo interno com o qual se pode lutar, e o qual se julga poder ultrapassar.

Em Lenoble, a "ordenação" ou racionalização da Natureza por Aristóteles, disciplina os deuses a uma ordem natural e boa que tende a seu fim, dá estabilidade e segurança ao homem. A revelação cristã adaptar-se-á então a esta racionalização (LENOBLE, p.186). Na racionalização aristotélica da Natureza reforçada com o adaptar cristão, Lenoble concilia os polos Lynn White e Passmore que respectivamente dão a responsabilidade da atitude ocidental dominadora sobre a Natureza ao cristianismo e a Aristóteles. O "adaptar cristão" de Lenoble já pressupõe que o cristianismo concorde com este âmbito racional. Mas para Girard é a revelação cristã que possibilitará definitivamente esta racionalização até aí incipiente. É o libertar da culpa que permite ver causas, é o libertar da culpa universalizado no cristianismo que permite estender o pensar causal para lá das elites. A elogiar o cristianismo, como causa do progresso material, Girard concordaria com White, o detractor

Problemata: R. Intern. Fil. v.6, n. 3(2015), p 283-319 ISSN 2236-8612 
do cristianismo ${ }^{20}$. Face aqueles deuses dos tempos heroicos que possuindo a sophia, o saber fazer, a habilidade na construção de objectos, (para Girard, novamente o mecanismo que, revelado, roubado aos Deuses pagãos, potenciará a ciência) a encobriam aos homens (HADOT, p.49), o homem cristão, pertencendo à transcendental graça sobrenatural, desgarra-se da natureza física, tem fim diferente da Natureza (LENOBLE, p.187). Se a Natureza é agora criação do criador, perfeitamente dela distinto, transcendente, cabe ao homem dominá-la ${ }^{21}$. Com ajuda neoplatónica, desgarra-se a alma do corpo, sacrificado como Natureza material, carnal, inferior. Girard concordaria que o reino de Jesus não é deste mundo, não é o mundo naturalmente sacrificial. À Natureza ainda modelo em versão aristotélica, contrapõe-se a agora a Natureza tentadora, corpórea, pecadora, resistente resto da graça. Aliás a ideia de criação, até pela introdução da linearidade anti-sacrificial cristã, diria Girard, ajuda a subjugar a Natureza, assim feita dependente de Deus. Essa eterna circularidade pagã, (tão ciclicamente sacrificial), tão fatal, com histórico e eterno retorno em ano grande, torna a Natureza invulnerável às tentativas de domínio do homem (LENOBLE pp.187-191). A revelação é acontecimento único impedido de admitir repetidas encarnações, paixões e ressurreições; o cristianismo liberta o homem da natural circularidade temporal, liberta-o, para Girard, da circularidade do mecanismo expiatório, da sua comunitária natureza mentirosa e sangrenta. Liberto desta sua natureza, o homem poderá então livrar-se de culpas e, progressivamente, de fins (estes ainda muito presentes na Idade Média Escolástica), para poder procurar causas. Em Girard, é esse Cristo revelador do mecanismo que permite a esse "relógio arbóreo" de Descartes ser a máquina modelo da Natureza, com Deus relojoeiro (HADOT, p.147) 22. O salto até Descartes é demasiado brusco. Hadot, Lenoble e Girard esquecem a importância da filosofia franciscana quer na destruição do fim aristotélico (Ockham), quer neste processo de coisificação da natureza. $\mathrm{O}$ voluntarismo de Duns Escoto e Ockham converte o decálogo a vontade divina arbitrária, e o seu nominalismo de negar realidade a toda a intermediação entre o indivíduo e Deus já prepara essa degradação e coisificação da natureza material sublimada na (não) propriedade franciscana do usus pauper (MILBANK, 2012) $)^{23}$. Com este impulso, podem então Bacon, Descartes e 
Hobbes reclamar o domínio e posse da Natureza coisificada (LENOBLE, p.192).

Este exemplo de derrapagem que, seguindo impulso cristão, extravasa para territórios não cristãos serve-nos para aqui introduzir 3 vias pelas quais.a revelação cristã se volta contra ela mesmo (GIRARD, 1994, p.19). Não de acaso, o cristianismo tenta controlar e gerir a culpa, logo no sacramento da reconciliação. A culpa, expulsa dos fenómenos naturais pela causa, ou tentará regressar às vítimas inocentes (retorno sacrificial), ou prosseguir descontroladamente no império da vítima, na competição mimética pela inocência, pela caça à culpa, sacrificial também, ou, tal a sua fluidez, a esconder-se mesmo na causa, a derrapagem mecanicista, que expulsando Deus potencia uma ciênciolatria, também sacrificial. Estas derrapagens estão intimamente ligadas à postura do homem face à Natureza e à sua natureza. Que já atrás, na exposição da quarta tese de Girard, aflorámos o império da vítima, prossigamos, com Hadot, pela derrapagem mecanicista (prometaica) e neosacrificial (órfica).

\section{A derrapagem mecanicista, Prometeu compromete-se.}

O prometaico cristianismo, revelador da mentira, destituidor do mentiroso mecanismo apontado aos inocentes, dador do fogo da verdade ao homem, promotor do progresso material, cria as condições para um movimento que se irá virar contra ele. A derrapagem mecanicista que perdura na ciência, revestida de elementos sacrificiais, ameaça fazer de Prometeu Frankenstein ${ }^{24}$. A natureza réu em tribunal, já no tratado hipocrático Sobre a arte, do séc. V (HADOT, pp.114-115), e no segundo prefácio à Crítica da Razão Pura ${ }^{25}$, prossegue também na versão objecto de tortura em experimental açougue para revelar seus segredos ${ }^{26}$. Se cortar às tiras faz bacon, o açougue de Francis Bacon fundará mesmo a ciência experimental moderna. Já atrás se falou do sistema judicial moderno como sistematização de interditos fundada a partir da vítima primordial. Não espantará então que este modelo judiciário de forçar verdade à Natureza em tribunal ou tortura, contenha também assim muitos elementos sacrificiais, sendo, para Girard, continuação, em muitos aspectos, da imolação ritual. As duas origens para o surgimento da pena capital que Louis Gernet dá 
em Anthropologie de la Grèce Antique vão empapadas de bode expiatório (GIRARD, 1972, pp.445-448): a condenação à morte em forma puramente religiosa (libertação purificatória, diluidora da responsabilidade pelo sangue do imolado, mais expulsão violenta, mortal mas devotada de membro maldito aproximada ao homo sacer e ao pharmakos) e condenação "puramente não religiosa" (o apagoge perante um delito flagrante de um estrangeiro, mais fácil de não poder ser vingado, de não soltar uma cadeia de violência interna, homologado pela colectividade). A vitima expiatória prossegue nas duas modalidades, permitindo a Girard afirmar que em ambas a unanimidade fundadora é linchamento gradualmente sistematizado e legalizado ${ }^{27}$. Ajunte-se a isto o caracter aleatório da vítima que se mantém noutras formas intermediárias do religioso e do judicial como o ordálio. Neste combativo modelo judicial, a perspectiva prometaica não se desliga de uma perspectiva sacrificial.

Todavia, a derrapagem está no facto do desvelamento do mecanismo expiatório, a negação da culpa inocente, trazer também em si a negação do Deus cristão. Substitui-se a culpa por causas; agora à solta, sem deuses, e, com o mecanicismo, sem Deus, a causa vai desteleologizar e depois desteologizar a realidade. Cristo, o modelo externo à boa distância, é expulso. Ainda que Bacon, Mersenne e Descartes não ponham atrito entre mecanicismo e fé, Deus está já semi-expulso, reduzido a primeiro pontapé de saída, pelo que cedo se descobrirá inútil (HADOT, pp.150,151,155). Descartes avisa que o seu sistema é mera hipótese explicativa podendo a realidade ser outra qualquer, dado a arbitrariedade absoluta de Deus poder estilhaçar até o princípio da não contradição (HADOT, p.154; algo, de resto, já muito antes admitido pelo voluntarismo de Ockham). Sacrifica a razão a um reforço glorificador da omnipotência da vontade divina para evitar posteriores inquisições. Leibnitz bem vê a equivalência entre esta vontade absoluta destituída de razão e o instituído acaso absoluto preenchido a átomos e vazio dos epicuristas. $\mathrm{Na}$ ausência de razão para o mundo, o que fica Deus a fazer? Onde o desvelamento do mecanismo mata os deuses, o mecanicismo explicativo por ele possibilitado vira-se agora contra Deus. O trágico é que, depois de expulsar Deus, a ciência tentará recuperar o sagrado. 
A ideia moderna no progresso, já com profundas raízes medievais, como Roger Bacon acreditando na revelação de toda a realidade, ainda que com santas intenções cristãs (HADOT, p.194), já parece apontar para uma remitificação. Como Moscovici (p.45) afirma, a ideia progressista (tão presente no positivismo e nos laivos mecânico-messiânicos da ciência actual) de um futuro conhecimento de toda a natureza / realidade implica crença - a crença na finitude numérica das coisas a conhecer, de que passo a passo, aumentando o número de coisas conhecidas em desfavor das por conhecer, nos vamos aproximando $^{28}$.

Mas talvez o mais interessante seja que a perspectiva de Moscovici acerca do avanço científico, "domínio" e exteriorização de domínio (produção, crescimento, desenvolvimento) sobre a matéria (se assim quisermos entender o que restou da Natureza face à atitude prometaica), pode ser interpretada de uma perspectiva sacrificial. A concorrência em forma cientifico-económica que hoje assistimos é então sacrificial porque essa violência canalizada ao desvelar e domar a natureza evita que a violência se atire definitivamente ao outro, ao rival: «au lieu de s'approprier sans détours les biens de l'autre, on l'autre, on essaie de maîtriser sa nature» (MOSCOVICI, p.9). O progresso como fim, objecto pretexto dos rivais em concorrência mimética, permite por enquanto mascarar o verdadeiro fim, suplantar o outro. A primazia do crescimento económico sobre uma perigosa e explosiva redistribuição, a preocupação em «remplacer l'exploitation de l'homme par l'exploitation des choses» (MOSCOVICI, p.13) pode ser encarado como todo um programa de canalização sacrifical, dos impulsos violentos ${ }^{29}$. Mas o pretexto é paliativo, já leva em si a semente da sua destruição, «le progrès technique est le moteur principal du rapprochement du travail manuel et intellectuel» (Moscovici, p.10); ou seja, em perspectiva mimética, este progresso conduz a uma progressiva igualização irresistivelmente conducente ao desencadeamento da violência ${ }^{30}$.

Quando, em Rousseau, a causa da desigualdade se muda da natureza (feita modelo a imitar socialmente em sua desigual harmonia) para a sociedade, tornando a desigualdade remediável (Moscovici, p.14), deu-se mais um passo na destruição das diferenças, mais lenha para a luta mimética. Se mesmo depois da revelação, até esta revolução de Rousseau, a natureza ainda 
era modelo externo, coisa exterior a imitar ${ }^{31}$, resta-lhe agora o destino que Girard dá aos modelos caídos, tornados internos; tornam-se objecto de cobiça. A natureza como modelo autoriza a que se lhe aplique o esquema mimético ${ }^{32}$. Por este, depois de imitada, a natureza foi suplantada, resta-lhe ser explorada ${ }^{33}$. Evidentemente que, para Girard, todo este processo foi desencadeado pela revelação cristã, originadora da progressão linear do tempo que mais e mais progride até se perceber, com Rousseau e a revolução (embora a revolução também tenha sido feita em nome da natureza, em nome do restabelecimento duma igualdade natural) que «L'histoire prit la place de la nature» ${ }^{34}$. Para Girard, Rousseau ${ }^{35}$ é apenas um passo nesta acentuação histórica. O que Moscovici chama exteriorização do mundo natural será, na perspectiva girardiana, o resultado da sua internalização como modelo seguida da sua ultrapassagem como modelo assim degradado a objecto de uso ${ }^{36}$, que, depois do trauma das revoluções e das grandes guerras, se reforça como pretexto sacrificial, jogo ritual de competição económica e científica, canalizador da violência mimética. O desvelar essa Natureza material torna-se assim um continuar a velar essas duas naturezas humanas. O progresso é, nesta perspectiva, definitivamente sacrificial, protector de uma luta e violência que seria bem mais destrutiva e pornográfica em versão nua. Palavra a Moscovici para ilustrar este caracter lúdico, logo sacrificial, da exploração, interiorização da natureza: «L'humanité se sent grandie lorsqu'elle remporte une victoire dans cette lutte sans merci.» Neste ambiente pós-revelação de mecanismo degradado a Natureza, ou mais propriamente cada degrau da Natureza que resiste a nosso esforço de domínio, é um misto de objecto pretexto por que lutar controladamente (sacrificialmente) e bode expiatório (sacrificial, também), causa de males a combater e domar. Em ambos os casos convém então que logo a seguir a uma vitória, ao ultrapassar de um "objecto expiatório", chamemos-lhe assim, se lute por nova vitória, novo objecto pretexto / bode expiatório que mantenha a coesão social pois «si la société se dégage de la nature, elle se reforme surtout contre elle.» ${ }^{37}$. Este "objecto expiatório" dá ao grupo o que conquistar, o que negar, o que expulsar pois interiorizar ou domesticar um obstáculo natural é uma forma de exteriorizar uma ameaça. Simmel (1992, pp.533-538) concordaria com Girard no caracter socializador e unificador da negação ${ }^{38}$. 
Mas veja-se como à luz da teoria mimética este sucedâneo sacrificial da concorrência económica e científica é perigoso por poder despoletar essa violência que contém: o nosso progredir deixa atrás de nós um rastro de natureza domada, previsível, humanizada, podemos arriscar aplainada, igualizada a nós ${ }^{39}$. Que este progresso domestica e igualiza mesmo o homem é ver como este mesmo se torna objecto de intervenção de melhoria do natural segundo padrões uniformizados numa indústria de implantes plásticos ou genéticos. $O$ que à domesticação científica resiste, é exterior, alvo a domar; o já domado, é objecto ultrapassado pelo qual já se não luta e deixa de servir de objecto pretexto. Ajuda então que, neste expediente sacrificial, onde a luta mimética é controlada a lutar por um objecto, a exteriorizar uma ameaça, se creia no eterno progresso, na eternidade de um objecto artificial na garantia eterna de um "objecto expiatório", um pretexto, afinal um não por que lutar controladamente, ritualmente, ludicamente. Como a crença num eterno Deus, o pretexto eterno ajuda a afastar a violência, vai mantendo esse sagrado afastado mas com consequências perigosamente igualizadoras, promotoras de violência.

O progresso que a revelação cristã despertou traz assim também em si muito de sacrificialidade não cristã. Dando um pretexto exterior, um alvo porque lutar, evita que a luta se torne interna. Mas este avançar em forma competitiva de todos contra todos já está perigosamente próximo dessa violência que se pretende afastar; é má vacina. O evitar violência de todos contra todos com competição de todos contra todos é versão degradada dessa sacralidade de evitar violência de todos contra todos com violência de todos contra um.

\section{O retorno de Orfeu em forma de Dionísio}

Oculta mas não extinta pela atitude prometaica dominante, prossegue a abordagem órfica com os alertas de Hadot (p.120) acerca do seu "primitivismo perigoso". A Natureza que se ocultou por boas razões desde Séneca, prossegue por Rousseau e, depois dos românticos, em Nietzsche (HADOT, p.113). Os desnaturados domínio e depois abandono da Natureza fazem, já no seculo XVIII, crescer remorsos reforçados pelo romantismo; a culpa, com a revelação cristã, progressivamente substituída pela causa, retorna agora em forma de angústia (HADOT 
pp.288,303). Perante a tortura violentadora da mãe Natureza por esse Prometeu, perante a falta, ou ineficácia, de mecanismo que expulse a angústia gritada por Pascal (Pensées 296, até porque o mecanismo também funciona internamente a expulsar demónios anteriores), regressam o terror e a volúpia face à Natureza. Em linguagem girardiana: nesta atitude órfica, despojado ou semiprivado de seu natural mecanismo, o homem quer recuperá-lo, quer regressar à Natureza, recuperar sua natureza sacrificial. A ressacralização da Natureza começa com Rousseau, feito assim ponto decisivo tanto na abordagem prometaica como órfica ${ }^{40}$; a Natureza «não quer cessar de continuar a ser» pelo que a reacção ao racionalismo do século XIX propõe um retorno ao irracional, ao instintivo, ao mítico ${ }^{41}$, concebido por Girard como repaganização ou retorno sacrificial.

Na recuperação de Schelling do movimento "respiratório" de sístole e diástole (HADOT, p.321) ${ }^{42}$ reconhece-se uma remitificação na sua Natureza, "mãe nutriz" do todo, que, em versões cada vez mais weimerizadas sobe seu segredo a segredo do ser (HADOT, p.322). Aliás, todo o movimento romântico é, por reação ao mecanicismo, esforço de repaganização, semente da proposta de retorno ao sacrificial. Bem Goethe ameaça de petrificação (novamente a grande mãe no seu aspecto medusiano, diabólico, mortificador do filho / marido / irmão), ou morte espiritual (próxima dessa uniformização, essa morte mecânica que Goethe já vê instalar-se no mundo ${ }^{43}$ ) aquele que ousar levantar o véu de Ísis (HADOT, p.273,274). A sua velha e sacralizada Natureza às claras, a qual pode aplicar-se tanto à natureza mimética como ao natural e mentiroso mecanismo, ocultos às claras ${ }^{44}$, é invisível a olhares profanos incapazes de a intuir em seus urphänomene (HADOT, p.277).

O Deus de Goethe, todo natureza e formas, variedade e diferença, concorda com essa perspectiva diferenciada da realidade, essa prudente diferenciação necessária à contenção da violência igualizadora em sociedade pré-cristã. Também Schiller conjuga a sua lamentação da partida dos deuses da Grécia com um tempo dessacralizado onde este mundo decairá até à catástrofe, para depois os deuses regressarem (HADOT, p.104107): a força da reacção anti-mecanicista prossegue impetuosa contra a revelação cristã. Em A Imagem Velada de Sais, Schiller mata o jovem que descobre ad deusa o véu; não se sobrevive a uma verdade terrível a que se terrivelmente chega «pelos caminhos do erro». E esta atitude sacrificial encobridora é 
confirmada em Cassandra: «vale a pena levantar o véu, lá onde o terror ameaça? Só o erro é a vida e a verdade a morte» (HADOT, p.292). Esta última afirmação faria as delícias de qualquer girardiano a descrever a mentalidade sacrificial. Podiase até contrapor, e é isso que conscientemente Schiller faz, com a esperança da revelação pela boca de Cristo: «o caminho, a verdade e a vida» (Jo 14:6), face ao volteio circular, à mentira e à morte presentes no mecanismo. Melhor, ainda: em $O s$ discípulos de Sais de Novalis, um homem ${ }^{45}$ levantando o véu da deusa vê-se a si mesmo. Para além desta Natureza ser aqui claramente essa natureza humana em que neste trabalho insistimos, o espelho (como os gémeos combatentes) é poderosa metáfora dessa natureza mimética e violenta do homem que o véu aqui, o mecanismo do bode expiatório, visa conter (HADOT, p.294). Estamos em plena atitude órfica sacrificial onde revelar a Natureza, ou, em versão reforçada, revelar o ser, é revelar o homem, sua natureza mimética e expiatória, diga-se violenta.

Sim, é "natural" que a desvelar a Natureza o homem desvele sua natureza, mas o que encontrará é essa verdade terrível, essa sua natureza violenta, destrutiva porque mimética e expiatória? Se o caminho que até aqui seguimos ainda parecer forçado e cheio de arestas por limar, a típica acutilância de Nietzsche vai suavizá-lo. Não de acaso, Girard fala da profunda intuição de Nietzsche no que concerne ao elemento sacrificial que propõe restaurar contra o cristianismo. A propósito do aforismo 125 em A Gaia Ciência, Girard sublinha que «Au lieu de dire : «Dieu est mort», Nietzsche dit en fait : «Nous l'avons tué. »(GIRARD, 2004, pp. 134,135). Ao invés da leitura tradicional, ocultadora do mecanismo, o aforismo 125, onde a já banalidade, à época, "Deus está morto" só uma vez aparece, contém a revelação do mecanismo, a matança colectiva e violenta de Deus como produção de Deus, como origem da religião, acrescentando até as instituições culturais, jogos e festas que se lhe seguirão. E grita o tolo a buscar Deus de lanterna em plena manhã, aos que dele se riem:

Para onde foi Deus? gritou ele, eu vos direi! Nós matámo-lo - vós e eu. Todos nós somos seus assassinos! Mas como fizemos nós isso? Como pudemos nós beber inteiramente o mar? (...) Deus está morto! Deus permanece morto! E fomos nós que o matamos! Como nos consolarmos, nós os assassinos dos 
assassinos? O mais sagrado e mais poderoso que o mundo até aqui tinha possuido, sangrou sob os nossos punhais - quem limpará de nós esse sangue? Com que água nos poderemos purificar? Que expiações, que jogos sagrados teremos de inventar? Não é o imenso desse acto demasiado para nós? Não teríamos nós mesmos de nos tornar deuses, para parecer apenas dignos dele? (Nietzsche, Die fröhliche Wissenschaft, § 125)

«La seul erreur de Nietzche, proprement luciférienne (au sens du «porte-lumière), c'est de choisir la violence contre la vérité innocente de la victime, vérité que pourtant il est lui, Nietzsche, seul à entrevoir face à l'aveuglement positiviste de tous les ethnologues athées et des chrétiens même.» $\mathrm{E}$ ao «XXe siècle et ses génocides» Girard dá uma clara origem : «tous les désastres causés par nos choix dionysiaques et sacrificiels» (1994, p.227). O erro de Nietzsche foi preferir Dionísio (concentração do maravilhoso olímpico, pagão), para ele a alegria e a força de viver, o excesso revitalizador, sacrificial mais uma vez, até nesse cíclico e pagão eterno retorno, a Jesus, para ele mortificação das forças da vida, repelente igualização plebeia que, nessa moral de escravos, toma o partido da vítima. Podemos agora prosseguir ao que Hadot cita de Nietzsche:

Devia-se respeitar mais o pudor com que a natureza se
oculta atrás de enigmas e de incerteza brilhantes. Talvez
a verdade seja uma mulher com boas razões para não
deixar ver suas razões? Talvez seja seu nome, para falar
grego, Balbo? Ó os gregos! Eles se entendiam no que
toca ao viver: coisa para a qual é necessário manter-se
corajosamente à superfície, nas roupagens, na pele,
adorar a aparência, acreditar nas formas, sons, palavra,
em todo o Olimpo da aparência. Esses gregos eram
superficiais por profundidade!

Só esta passagem já chegaria para colocar Nietzsche na tradição órfica, aqui conscientemente sacrificial. Como Schiller, Nietzsche tem de se lançar no ataque à verdade. O homem sobrevive então da mentira (HADOT, p.307), dessa aparência superficial e sacrificial, dessa velação do mecanismo. Recuperese então o erro quando a plebeia e cristã insistência na verdade violenta, destruidora dessa superfície vital de erro e aparência, nos atira a essa realidade terrível onde, privados dessa respiração cíclica, cega e sacrificial, sufocamos caídos no 
mundo pós-revelação do mecanismo degradado. Que Dionísio, a vital ilusão, afaste Cristo, a mortífera verdade. O cristianismo, revelador do mecanismo, revelador de Dionísio, para Girard revelador de Satã, pai da mentira, deixa-nos naquela verdade desvivificada do cadavérico asceta cristão (HADOT, p.308). O maravilhoso pagão, pregado com mentiras míticas e rituais e colado a sangue inocente, é essa superficialidade profunda de que os homens sobreviviam. A verdade de Nietzsche é então de superficial essência mentirosa, não se despe do véu, da abundante aparência que dá formas à vida (HADOT, p.313). Em ciclo dionisíaco, no seu jogo eterno, nessa vida que continuamente jorra a destruir e recriar todas as formas, pode então a morte dar e ser vida, a mentira dar e ser verdade, o horror dar e ser beleza (HADOT, p.317). Dificilmente poderíamos ter melhor descrição de um universo sacrificial assente no mecanismo. Não admira então que Nietzsche queira proteger o véu. «A sabedoria no homem ao permanecer superficial (sacrificial, diria Girard!), é seu instinto de conservação que o incita a ser precoce, ágil e falso (HADOT, p.309) ${ }^{46} » ; \mathrm{E}$ as «boas razões (Gründe) para não deixar ver suas razões (Gründe) ${ }^{47}$ são a conservação do mais íntimo e profundo no homem, são o órgão reprodutor, conservador da humanidade, da sua natureza. Nestas razões ocultas, neste seu íntimo pudibundo, reencontra-se aquela ligação entre morte, sexo, revitalização e violência, a obsessão de Bataille. Seja Balbo por detrás do véu, a decrépita e impúdica mulher, seja demónio aterrador (HADOT, p.314,316), ou mesmo Hécate de lua decrescente (ver nota 9), a sua aparição continua a matar, como desde os românticos. Parece-nos também correcta a interpretação de Hadot, porque literal, da convicção da condenação do individual face à reconciliação de tudo na totalidade, terminada com «tal fé batizei com o nome de Dionísio» (HADOT, p.320) ${ }^{48}$. Mas ler-se-ia talvez aí melhor um sugerir do mecanismo, o sacrifício da parte pelo todo, essa violência parcial a vacinar da violência total, a reconciliar o total.

Como Girard a traçar a história do retorno sacrificial (1994, pp.21,123,227), Hadot prossegue de Nietzsche a Heidegger a traçar a história da atitude órfica. Girard concorda tanto com Heidegger como com Nietzsche no diagnóstico para discordar na solução. Acerca do eterno retorno, sacrificial, «les néo-païens, Nietzsche et surtout Heidegger s'efforcent de le 
ressusciter. Quand Heidegger disait au Spiegel : «Seul un dieu peut nous sauver» (...) ce n'est pas au Dieu de la Bible qu'il faisait allusion mais à un nouveau Dionysos, à un renouvellement cyclique total»(GIRARD, 1994, p.122). E a postura órfica de Heidegger não deixa de denunciar, à maneira de Goethe, um velamento por detrás do desvelamento da natureza; o progredir da técnica. Mas quando para Heidegger a filosofia tende a ser história do velamento do ser e seu esquecimento (onde physis é esse mistério do desvelar que é velar (HADOT, p.327)), leia-se em Girard ocultação do mecanismo sacrificial, pensamento sacrificial em si que concorda com o quotidiano a cegar o homem do eclodir das coisas, da sua physis ${ }^{49}$. O cego de não querer ver, o cego sem o bastão do mecanismo sacrificial, erra então esse errar denunciado por Heidegger, errar agitado de objecto em objecto (HADOT, p.328). Com efeito, cegos no mundo, no mimetismo, não vemos nem a nossa natureza mimética (esta ainda menos hoje dada a fé no sujeito autónomo e racional) nem a nossa social natureza mentirosa, na forma do mecanismo que sobrevive entre nós em forma degradada. O homem ama ocultar-se.

\section{Anexo: As quatro teses de René Girard}

A tese basilar de Girard, principalmente desenvolvida em Mesonge Romantique et Vérité Romanesque (1961), impossibilita a relação entre sujeito e objecto sem um terceiro elemento, o mediador ou modelo: só por um terceiro desejar ou ter determinado objecto, o sujeito deseja esse objecto. Assim se forma o triângulo mimético sujeito - modelo - objecto. Além dos apetites instintivos, o desejo só o é quando mimético; o desejo, e mesmo o próprio homem, nasce desta triangularidade, podendo assumir duas formas. Se o modelo B, afastado do sujeito $A$, não lhe pode oferecer reciprocidade, está-se numa mediação externa inofensiva. Amadis, o modelo de D. Quixote, é personagem vivente em romances de cavalaria, impossibilitada de retorquir a seu imitador. Não se tocando os raios de possibilidade do sujeito e mediador, mantém-se entre eles uma diferença, uma distância física, social ou intelectualmente intransponível. Mas estando o modelo $\mathrm{J}$ suficientemente próximo do sujeito I para haver reciprocidade, já se tem uma

Problemata: R. Intern. Fil. v.6, n. 3(2015), p 283-319 ISSN 2236-8612 
mediação interna ${ }^{50}$. Agora aqui, o modelo, ao perceber a imitação do sujeito e pressenti-lo como apropriação intrusiva, opõe-se. Agora os raios de possibilidade do mediador / modelo e do sujeito colidem. Assim desencadeada a rivalidade mimética, torna-se também o modelo J rival imitador do imitador sujeito I; em luta pelo objecto-pretexto, I e $\mathrm{J}$, feitos modelos rivais um do outro, aproximam-se e depois igualizam-se mimeticamente pela lógica violenta do olho por olho. Em luta pelo lugar do modelo, I e J são já indistintos; o objecto revela sua sua importância meramente "pretextual", é esquecido. Concentrados no seu oponente, os dois combatentes desvelam a verdadeira causa da luta, o recíproco desejo de apropriação de ser: tentar derrotar, ultrapassar o rival, tentar apropriar-se do modelo antes ali e agora tão aqui, ser agora esse modelo. Mais persuadidos de sua diferença, mais igualizados na violência; ambos agridem certos de justa resposta a uma agressão primeira, culposa, do próximo. Não sendo barrado, o triângulo, agora círculo de violência indistinta a dois, contagiar-se-á miméticamente a toda a sociedade ameaçando-a colapsar em modo de todos contra todos. O próximo é perigoso de imitar. Modelos mais internos, próximos e reais, modelos menos transcendentalizados, são mais susceptíveis de reagir e contestar. Pode assim a contagiosa rivalidade generalizar-se em violência mimética onde, progressivamente anuladas as diferenças, todos violentamente se igualizam, são a uma vez sujeitos e modelos, ameaçando colapsar a sociedade.

Nesta tese Girard denuncia a, por si baptizada, mentira romântica mentira fundamental que segue na base das concepções sociais, políticas e económicas dominantes; em rol de auto-bajulação, tem-se o sujeito como independente, autónomo, racional, desejante por si.

A segunda grande tese de Girard respeita ao mecanismo do bode expiatório ${ }^{51}$. Imersa toda uma sociedade nessa crise mimética, nessa violência igualizadora de todos contra todos, e presente o sagrado entre os homens a contagiá-los com sua perigosidade violenta e indiferenciadora ${ }^{52}$ ou o mecanismo do bode expiatório intervém ou a sociedade implode sobre si mesma. Como intervém o mecanismo? A indiferenciação da violência mimética, alimentada em espiral até ao todos contra todos onde todos são indistintos converge para outra similitude mas agora unida porque em forma de todos contra um. Este qualquer é unanimemente feito culpado de todo o mal 
desordeiro; a sua expulsão, por sua morte colectiva, concentra em si todo o mal e desordem, todo o sagrado violento a expulsar para purgar a sociedade. Uma qualquer marca de vítima, uma qualquer diferença detectada na vítima ${ }^{53}$, ateia e propaga de certezas, em sua arbitrariedade, o palheiro alucinogénio da crise mimética. Tendo culpa com rosto, tendo culpado quem precisa de causas? A unanimidade acerca da culpa da vítima constitui prova suficiente; e da sua morte violenta resulta de facto a união negativa da comunidade. Em lógica de vacina, a parte pelo todo, a violência unânime sobre um salva todos da sua violência unânime. A exteriorização do sagrado / violência é aqui a sua expulsão na figura maléfico da vítima. Assim ausente, pode agora voltar seu benéfico refluxo. Confirma-se como este bode expiatório é pharmakon, concentra em si as clássicas ambivalências do sagrado: é impuro e purificador, maléfico e benéfico, mortífero e salvador, remédio e veneno. A vítima maldita e culpada da desordem é agora divinizada, é agora fundação e depois fundamento da ordem social: é modelo que assim transcendentalizado repõe a boa distância, a mediação externa. E esta vítima expiatória é ainda mais fundamental fundação quando Girard a coloca como base da hominização e de toda a sociabilidade humana. Nela assentam todas as instituições culturais que, ou são barragens, ou são canalizações da violência informe de se dar a toda a forma primeiramente nos mitos, interditos e ritos sacrificiais.

Nos mitos, a partir de um caos primordial (qual poderá também ter forma de peste contagiosa e destruidora das diferenças ou de dilúvio igualizador), a perspectiva dos matadores descreve camufladamente uma crise mimética de todos contra todos narrando a sua resolução ordenadora: a morte colectiva duma vítima culpada. Para Girard a narrativa mítica e sacrificial, desde o racionalismo das luzes ao estruturalismo de Levy-Strauss, conscientemente ou não, persiste cega a este crime e mentira fundadores, insiste no seu encobrimento.

Os interditos são experiência do bode expiatório e da crise anterior; instituem tabus e proibições a dividir e separar, tentando desincentivar potenciais rivalidades, evitar igualizar o desejo sobre os potenciais objectos de discórdia. Não espanta, que nesta lógica possam também revestir a forma de barreiras e divisões sociais, económicas e políticas. O incesto é exemplo imediato de tabu primitivo e universal: interdite-se o objecto sexual mais disponível, logo mais propiciador de conflitos. 
Nesta boa negatividade, óbvio sistema de interditos é o sistema judicial. O direito, feito exterioridade ou terceiro, concentra num acto (sacrificialmente) a vingança, eliminando assim a troca, a sua propagação ou reciprocidade violenta ${ }^{54}$.

Os ritos e sacrifícios imitam, re-presentam a crise e sua resolução. Depois da festa, da re-presentação do caos primordial ou da crise mimética, o sacrifício. Agora, toda a comunidade se tenta rebanhar de coesão: à maneira do campo de jogo de Huizinga em Homo Ludens, ou seja, em modo, tempo e lugar estritos (não vá essa violência ou sagrado a utilizar galgar as fronteiras do rito e incendiar toda a comunidade), transgride-se, repete-se a violência fundadora, o mecanismo, sobre a vítima de substituição. Dando vazão controlada às energias violentas entretanto acumuladas, repete-se o sucedido mecanismo fundador para renovar seu sucesso, a união da comunidade. Pode acrescentar-se a Girard que esta gestão sacrificial da violência continua hoje presente nos espetáculos ou jogos de massas, com ritualização da excepção transgressora em espaço, tempo e modo.

Fundados pela vítima expiatória, interditos, mitos e ritos visam: ou conter directamente a violência, ou, a outra forma de a conter, exteriorizar essa violência na base do próprio mecanismo. As formas de diferenciação social, formas de mediação externa que desviem do perigoso porque igualizado desejo a um objecto pretextual, são essenciais a resguardarem a comunidade da sua própria violência. Que já se tratou da justiça, refiram-se agora os ritos de iniciação (repetição pessoal duma crise com violência, morte e renascimento), o rei sagrado (entre terra e céu, ambivalência transgressora, nalgumas culturas efectiva ou simbolicamente sacrificado para restaurar a ordem), os ritos funerários e alimentares, o dom e contra-dom, as festas, a domesticação animal (ditada pela necessidade de vítimas substitutivas para os rituais): toda a cultura acaba, para Girard, por remeter à vítima emissária.

Quando, corroído pelo impurgável desejo mimético, todo este sistema em mitos, interditos, e ritos sacrificiais deixa de conter e expulsar eficazmente a violência ou sagrado; quando este sagrado, anunciado na proliferação de modelos internos, se aproxima de uma sociedade e depois nela cai, efectivado na crise mimética, nessa igualização violenta, só sobreviverá com nova vítima constituinte de outro sistema cultural. A cultura humana é um progredir picotado de ciclos vitimários, cada qual

Problemata: R. Intern. Fil. v.6, n. 3(2015), p 283-319 ISSN 2236-8612 
com vários ciclos sacrificiais; até Cristo, a história será esta necrologia dos inocentes em espirais sacrificiais e tangentes expiatórias.

À terceira tese de Girard ${ }^{55}$ : desde Abel, onde Deus toma partido do inocente pedindo contas a Caim ${ }^{56}$, passando por José inocente e Job a reclamar sua inocência, seguindo pelo $4^{\circ}$ canto do servidor de Javé no $2^{\circ}$ livro de Isaías, até à culminação nos Evangelhos e mais especificamente na paixão, a Bíblia inocenta e humaniza o bode expiatório. A novidade de um discurso conscientemente desmitificador e desmistificador cresce até à anti-sacrificialidade militante da vida e da morte de Cristo - isto se evidentemente se considerar que a morte de Cristo não foi também ela um sacrifício para acabar com o sacrifício dos inocentes, para revelar o mecanismo. É a morte, a mentira, a violência fundadoras, o mecanismo violento de combater a violência em forma de Satã, que Cristo repudia nas tentações. O dar a outra face de Jesus nega, interrompe a cadeia de violência do olho por olho mimético. A revelação é revelação do mecanismo; começada na sua denúncia verbal ${ }^{57}$, culmina na paixão e morte de Cristo. O mecanismo escolherá Cristo como vítima. Pouco depois da sua entrada triunfal de burrico em Jerusalém, o mimetismo unânime coloca todos, apóstolos e Pedro incluídos, contra Cristo que, nunca deixando de clamar sua inocência, aceita fazer de bode expiatório. Se os evangelhos falam a linguagem sacrificial, religiosa, se com isto se mascaram, é para melhor desmascararem o discurso sacrificial e religioso $^{58}$. Agora, ganhando as vítimas verbo que por elas fale, é a inocência explicitada do cordeiro de Deus quem expulsa o bode expiatório;.

Quarta grande tese de Girard ${ }^{59}$ : mecanismo revelado é mecanismo degradado pelo que, sem este instrumento de gestão da violência, o apocalipse, a revelação na cruz, veio provocar o começo do apocalipse em sentido escatológico. É para este que, em novo tempo linear cristão, uma humanidade cada vez mais uniformizada, mais igual, mais violenta progride e em progressiva aceleração. Tente-se pormenorizar a quarta tese. A unanimidade do mecanismo, o todos contra um garantidor da sua eficiência, era dado pela ignorância do mecanismo. A inocência de Cristo revela-o, revela o crime e a mentira fundadores, revela a inocência de todas as vítimas expiatórias: "bode expiatório" significa agora "inocente". A causa pode agora emancipar-se da culpa. O desencantamento da vítima

Problemata: R. Intern. Fil. v.6, n. 3(2015), p 283-319 ISSN 2236-8612 
culpada e depois divinizada permitirá o desenvolvimento da ciência, a economia concorrencial, o progresso material.

Mas a revelação não destruiu um mecanismo em que assenta a própria hominização. Ele permanece embora perigosamente adulterado. Impossível agora o todos contra um; nem o "todos" (a perda da unanimidade atirada à vítima como já referido), nem o "um", a unicidade da vítima única. Os bodes tendem precariamente a ser um grupo, grupos que se sucedem arbitrariamente, incapazes de se divinizarem, incapacitados de dar coesão duradoura, mais propensos a despoletar em banho de sangue essa violência que deveriam exteriorizar controladamente: a culpa é das bruxas, dos judeus, dos árabes, dos americanos, dos bancos, dos ricos, dos pobres não empreendedores, dos políticos, dos estrangeiros que ocupam o lugar dos nacionais. O perigo é aqui é a resposta Maia de tentar buscar o efeito catártico perdido do mecanismo, substituindo uma vítima, por muitas, por uma multidão em holocausto ou genocídio, em Girard, consabidas formas modernas degradadas do mecanismo. Ainda outro efeito perverso: o cristianismo soltou a vítima; agora sem perecer, esta impera; solta-se o império da vítima, perpetuando cínica mas mais perigosamente, o mecanismo degradado. Qualquer indivíduo ou grupo se faz vítima para vitimar. A vítima feita inocente está habilitada a perseguir, persegue reciprocidade mimética os seus pretensos perseguidores. Toda a guerra agora se faz para pacificar.

Ao mecanismo degradado duma sociedade assim menos capaz de expulsar sua violência junte-se o esbatimento progressivo de interditos, barreiras e diferenças, a uniformização política, social e cultural do mundo. Mais igualdade é, em Girard, mais desejo unânime, mais violência. O terrorismo (tão invisível quão cego a atacar indiscriminadamente sem prévia selecção de vítimas) é avanço do começado na conscrição geral da França revolucionária e prosseguido na guerrilha do partisan invisível da Guerra Peninsular: cada vez mais longe do pudor diferenciador com prisioneiros, crianças e mulheres, aproximamo-nos da indiferenciação mimética, das violência e guerra totais já previstas no elevar aos extremos de Clausewitz. O 11 de Setembro não se deve a diferenças culturais mas ao seu esbatimento global. Odeia-se o ocidente, odeia-se porque se ama o modelo a imitar ${ }^{60}$. Sem a segura e diferenciadora circularidade do tempo pagão, impõe-se a aplainante linearidade cristã; a humanidade segue ao apocalipse catástrofe. A previsão 
apocalíptica dos filhos em guerra contra pai e mãe, é para Girard típico fenómeno da violência indiferenciadora duma crise sacrificial.

No quadro girardiano, Cristo é acelerador (dada a revelação deterioradora do mecanismo) mas também o katechon refreador do apocalipse em sentido escatológico. A única esperança será renunciar ao mimetismo violento pela ciência cristã de dar a outra face, será imitar Cristo, o modelo externo à justa distância.

\section{Referências}

BURKETT, The Creation of the Sacred, Tracks of Biology in Early Religions, Harvard University Press, 1996.

DIELS, H. e KRANZ, W, I Presocratici, Direc. Giovanni Reale, Milano: Bompiani, 2006.

DUPUY, Jean-Pierre, Petite Métaphysique des Tsunamis, Paris: Éditions, Seuil, 2005.

. La Marque du Sacré, Paris: Carnets Nord, 2008.

ELIADE, Traité dhistoire des Religions, Paris: Éditions Payot, 1975.

FRAZER, The Golden Bough, New York: The Macmillan Company, 1922.

GIRARD, René, Mensonge Romantique et Vérité Romanesque, Paris: Éditions Grasset \& Fasquelle, 1961.

La Violence et le Sacré, Paris: Éditions Grasset \&

Fasquelle, 1972.

. Des Choses Cachées Depuis la Fondation du Monde, Paris: Éditions Grasset \& Fasquelle, 1978.

. Le Bouc Émissaire, Paris: Éditions Grasset \&

Fasquelle, 1982.

. Quand ces choses commenceront... Entretiens avec

Michel Treguer, Paris: Arléa,1994.

La Voix Méconnu du Réel, Paris: Éditions Grasset \&

Fasquelle, 2002.

2004.

. Les Origines de la Culture, Paris: Desclée de Brouwer,

. Achever Clausewitz, Paris: Carnets Nord, 2007.

GRAVES, The Greek Myths, London: Penguin Books, 1987.

HADOT, Pierre, O véu de Ísis, Trad. Mariana Sérvulo, São

Paulo: Edições Loyola, 2006. 
HARDING, Les Mystères de la Femme, Paris: Éditions Payot, 2001.

LENOBLE, Robert, História da Ideia de Natureza, Lisboa: Edições 70, 1990.

MILBANK, John, "Against Human Rights: Liberty in the Western Tradition", in Oxford Journal of Law and Religion, pp.1-32, Jan 2012.

MOSCOVICI, Serge, Essai sur L'Histoire Humaine de la Nature, Paris: Flammarion, , 1977.

ORLEAN, André, AGLIETTA, Michel, La Violence de la Monnaie, Paris: PUF, 1982.

OUGHOURLIAN, Jean-Michel , Psychopolitique, Paris: François Xavier de Guilbert, 2010.

PASSMORE, J., The Perfectability of Man, Indianapolis: Liberty Fund, 1969.

RIBEIRO DOS SANTOS, Ideia de uma Heurística Transcendental. Ensaios de Meta-epistemologia kantiana, Lisboa: A Esfera do Caos, 2012.

SERRES, Michel, "Rousseau, juge du Législateur", in Parasite, Paris, Grasset, pp.160-161,1980.

SIMMEL, Georg, Soziologie - Untersuchungen über die Formen der Vergesellschaftung, Gesamtausgabe Band 11,: Frankfurt am Main: Suhrkamp taschenbuch wissenschaft, 1992. . Philosophie des Geldes, Gesamtausgabe Band 6, Frankfurt am Main: Suhrkamp Taschenbuch Wissenschaft, 1989.

WHITE, L. "The Historical Roots of our Ecological Crisis", in Science, 155, n⿳30767, pp. 1205-1207, 1967.

\footnotetext{
${ }^{I}$ Já, de resto, presente nos animais, logo na sua forma de aprendizagem, ou, se quisermos, aculturação.

${ }^{2}$ As pesquizas de Lorenz apontam também para um desviar da agressividade para um terceiro, uma instintividade do mecanismo do bode expiatório. (GIRARD, 2004, pp.149-151).

${ }^{3}$ Moscovici, p. 34.

${ }^{4}$ A atitude órfica será à partida de evidente velamento, mas este velamento será em muitos autores órficos o próprio desvelar (velado) da natureza.

${ }_{5}$ a partir de François Jacob, la logique du vivant (1970) e Jean Ruffié, Le sexe et la mort. (1986).

${ }^{6}$ de Aristóteles, Do céu, I, 4, 271 a33; II, 11, 291 b12 e Geração dos Animais, II, 6, 744 a35.

${ }^{7}$ Burkett (1996) vê aqui, neste dar a parte pelo todo, as raízes biológicas da religião, nessa lógica sacrificial presente desde a lenda do castor que se castra para se salvar do perigo, ao mito do anel de Polícrates, prosseguindo
} 
no sacrifício do rei tribal ou pré-clássico de Frazer (1922) que deve morrer no auge.

8 inspirado em Van der Leeuw, La religion dans son essence et ses manifestations. (1970).

${ }^{9}$ Não sendo aqui o lugar para dar o devido desenvolvimento a este tema, podemos adiantar (a partir de Graves (1987), Harding (2001) e Eliade (1975)) que a grande mãe neolítica, agrícola e telúrica, asseguradora da fertilidade e fecundidade dos campos e das mulheres, perdurou pelas civilizações orientais na forma da Astarte cananita, Istar babilónica, Ísis egípcia, Cibele frígia, Anahita persa, também a Anu céltica, e suas “importações” gregas. Para além dos seus atributos partogénicos (mais do que indicar virgindade, o termo indica a não precisão de macho para procriar podendo referir-se tanto a virgem como a prostituta, daí a ritual prostituição sagrada nalgumas culturas), a Deusa, em suas desvairadas formas, tende a ser tendencial virgem-mãe com filho-irmão-marido que, coitado, morre pós-coito para depois ressuscitar. Já o aparato simbólico comum é composto essencialmente por lua, serpente e seios desnudados. A lua: com 28 dias de ciclo correspondentes à menstruação, leva instabilidade na forma, (que a faz mesmo "engravidar" em lua cheia), no movimento (quantas vezes ela nasce com o sol ainda no céu), e na luz (as formas incertas do luar); é feminina praticamente em todas as culturas espalhadas em tempo e espaço (boa contradição da força, estabilidade e "clareza" do sol como arquétipo da masculinidade e racionalidade), com utilização preferencial da fase crescente (quantas vezes em forma de cornos taurinos, animal lunar por excelência, ainda hoje símbolo da abundância). Acrescente-se que a Deusa é representada numa tríade lunar cíclica correspondente ao quarto crescente, lua cheia e minguante, com paralelo na importação ou assimilação grega, aqui demasiadamente simplificada, em mulher virgem ou ninfa renascida (Artemisa), mulher fértil procriadora (Afrodite), mulher decrépita, infernal, destruidora (Hécate). A serpente: antes de ser diabolizada em cultura nómada, pastorícia e patriarcal (onde é a terra que dá subsistência, tem-se tendência para cultura matriarcal; onde é o gado, com macho dominante de cobrir fêmeas em redor, temos cultura fálica, patriarcal) é tida como partogénica devido à invisibilidade dos seus órgãos sexuais e à sua mudança cíclica de pele interpretada como autorenascimento, auto-regeneração; não espanta por isto a serpente regeneradora de Hipócrates. Os seios descobertos: comuns desde a grande deusa oriental às suas versões posteriores, descobrem o seu carácter de mãe protectora e nutridora. Tudo na grande mãe e suas posteriores versões, laicizadas ou não, grita essa eterna regeneração cíclica, lunar, sacrificial bem atestada no castigo, morte e ressureição mítica do filho/irmão/marido Thamuz, Osíris, Adonis, (até, de certa forma, Cristo) ou mesmo na castração ritual dos seus servidores, tudo nela clama capacidade de nutrir e regenerar. É lamentável que Hadot não tivesse entrado no aspecto sexual tão ligado ao sacrifício e à morte pois o incesto, morte e ressureição que precisa de ser periódica e ritualmente cometida e posteriormente castigada, acompanha os cultos e os mitos da Deusa. A Isis intelectualizada que perdura até ao sec XIX é a grande mãe que, à maneira das deusas neolíticas, da loba de roma, das virgens de leite medievais (veja-se ainda hoje como a representação da

Problemata: R. Intern. Fil. v.6, n. 3(2015), p 283-319 ISSN 2236-8612 
N.S. da Conceição não dispensa quarto crescente (ou corno) nem serpente) $e$ na República desnudada de Delacroix ou mesmo Daumier em 1848 (aqui, uma República musculada nutre dois meninos em cada seio, enquanto segura a tricolor), dá de mamar. Não espanta então, Hadot, que essa natureza mulher nua do sec XV a regar de leite o mundo, reapareça, no século XVII, nua com mamilos inchados de leite e nas festas revolucionárias (fonte de regeneração erigida em 10/8/1792) acompanhada por um abutre. Este, imagine-se, «simboliza a natureza pois todos são do sexo feminino, procriam sem precisão de macho» (HADOT pp. 255-258). É por isso que, no modelo de Artémis no séc. XVI, a explicação para os múltiplos seios de Ísis aos quais diferentes animais, à cintura, tentam chegar, como sendo adornos que revestiriam a deusa em estátua é despropositada. Ela é a grande mãe que dá de mamar a todos os seres vivos, é compreensível que tal potência nutridora, à maneira de loba (e aqui não será indiferente a generalizada conotação em diversas línguas de loba / prostituta equivalente a virgem partogénica), se vá apetrechando de mais e mais seios. A inscrição de Sais, onde uma Ísis Atena, virgem, diz: "eu sou tudo o que foi, tudo o que é, tudo o que será e meu véu (peplos), nenhum mortal ainda suspendeu” (HADOT p. 286 de Plutarco, Ísis e Osíris, 9, 354C) atesta a sua eterna e cíclica regeneração (pelo menos o seu contínuo ressurgimento confirmou-se nas laicas representações da República desnudada). Bem Plutarco a interpreta como virgem mãe que engendrou sozinha o sol, elemento masculino. É esta mãe eterna, de cíclica e sacrificial regeneração, esta mãe que nutre, protege, dá colo (veja-se a Madonna, a representação mais difundida da Virgem Maria, cujo título de mãe de Deus, mais que feliz coincidência, é proclamado em Éfeso, capital de Artemisa), contraposta ao elemento masculino, racional, solar (aliás, valeria a pena rever a história do arquétipo luz / sol da razão qual, desde a antiguidade, passando por iluminadas épocas, perdura ainda hoje nalguns logotipos de algumas sociedades de filosofia analítica) que a perspectiva órfica não deixa esquecer.

10 de República III, 391e-397d.

11 Sendo a tragédia sacrificial, não deixa de parcialmente desvelar o mecanismo sacrificial. Édipo, típico bode expiatório, culpado do mal pestilento de Tebas, provocador da queda das diferenças, do caos violento, é posto em tragédia, é semi-inocentado. Põe-se a tragédia a substituir a violência original não através da usual vítima ritual, mas através de uma teatralização (assim também ritual) onde a perseguição do destino atirada a um herói vítima, purga os espectadores, provoca uma katharsis colectiva (GIRARD, 1972, pp.434,435). Não espanta assim que a khatarsis de A Poética de Aristóteles seja também sacrificial substituindo essa já substituição que é a imolação ritual. Girard chama mesmo a esta obra manual de sacrifícios, tais as qualidades do bom herói: nem mau nem bom, posicionado à boa distância de nem dentro nem fora, conjugando semelhança e dissemelhança nessa marginalidade identificadora com o espectador que o faz boa vítima sacrificial, bom objecto purgatório para em tragédia dar à morte. (GIRARD, 1972, pp. 435,436);

12 Derrida demonstra como todas as traduções modernas, desenvolvendo esse esforço separador de Platão, se aplicam a apagar os traços desta 
duplicidade do pharmakon distinguindo artificialmente remédio e veneno (GIRARD, 1972, p. 444).

13 Finalmente, refira-se que não será forçada brincadeira ver também na controlada lotaria que determina a natureza do bode expiatório (ver nota 4), tanto pela arbitrariedade da escolha, como na natureza ambígua, sagrada deste (maléfico e benéfico, interior e exterior à comunidade) a forma de actuar dessa Natureza brincalhona referida por Hadot desde a criança de Heraclito a jogar aos dados (frg. 52b), com continuidade em Séneca, Plínio, Diderot e no jogo sacrificial de Dionísio tratado por Nietzsche (HADOT, p.224).

${ }^{14}$ Bem Estrabão mantém que os mistérios de Eleusis imitam a natureza do divino que se esconde (HADOT, p.64).

${ }^{15}$ Aliás, já em Heraclito, «na circunferência do círculo, o princípio e o fim coincidem» (Frag. b103).

${ }^{16}$ Hadot, p. 75.

17 Juliano o apóstata tentou organizar uma hierarquia clerical pagã à maneira da Igreja cristã (Carl Grimberg, História Universal, Vol 5, Trad. Jorge de Macedo, Europa-América, 1966, p.200), cuja hierarquia já mimetizava aliás a do império.

${ }^{18}$ Hadot, pp. 91,96,97.

${ }^{19}$ de Lucullus, 39, 122.

20 Para além da linearidade temporal cristã a possibilitar uma fé cristã ilimitada no progresso, do Deus do Génesis a dar o domínio dos animais e da terra ao homem, e da transcendência que faz o homem partilhar com Deus sobre a Natureza, White aponta também a destruição das religiões animistas pagãs como possibilitadora da exploração desapiedada da natureza. A ciência, fundida com a técnica, é apresentada como extrapolação da teologia natural cristã de onde, após de se tentar ler a natureza como reveladora da divindade e assim meio desta comunicar, se passará a vê-la como reveladora da mente de Deus, do modo como a criação funciona; até a hipótese de Deus se tornar inútil.

${ }^{21}$ A célebre passagem de Gen 1:28.

22 Isto não prejudica que este modelo máquina se funde na destruição de outra máquina. Repete-se como é revelador que Girard chame mecanismo ao mecanismo do bode expiatório. Se méchané, é técnica ou ardil grego de contrariar a Natureza (HADOT, p.116), o natural mecanismo de Girard $\left(2^{a}\right.$ natureza) é exactamente ardil, mentira, de evitar a destruição a que a nossa primeira natureza o natural mimetismo, a violência mimética, nos empurra, sedimentado pelas instituições culturais, mitos, ritos e interditos, verdadeiros instrumentos fabricados.

${ }^{23}$ Dado o voto de pobreza, os franciscanos querem poder usar bens sem que deles tenham propriedade. Insistindo numa separação entre propriedade e uso (até aí estranha à mentalidade medieval), solta-se a propriedade de todas as suas restrições e fins (para a escolástica a posse de um bem como direito não se desligava de um recíproco dever nem de um fim). Para que uns possam usar sem possuir é aliás preciso que outros possam possuir sem usar, bom germe do princípio de acumulação capitalista, também na raiz do progresso material. 
${ }^{24}$ Embora Kant, na Crítica do Juízo, tenha, principalmente no parágrafo 65, ultrapassado este mecanicismo primário, substituindo a relojoeira metáfora racionalista pela do organismo (RIBEIRO DOS SANTOS, 2012), subordinado o mecanicismo a uma teleologia que, não abolutizada, se livra de cair a comprometer a liberdade e depois a moralidade, afinal o que o mecanicismo compromete, isso não impediu o seu regresso periódico, cuja versão actual segue a forma do algoritmo informático, máquina modelo dador de ordem e sentido a todo o universo.

${ }^{25}$ Kant conjuga para Hadot tanto esta atitude prometaica como a órfica, principalmente na Crítica do Juízo, onde a postura perante a natureza segue pejada de respeito e admiração (HADOT, p. 285). Também (Crítica do Juízo, 42, AK, V, 167) a degradação do interesse imediato pela Natureza, caído a um interesse mediato (ou próprio, ou interesseiro, noutras formulações) de vaidade apontado à sociedade, mal se detecte uma imitação da Natureza, espelharia para Girard essa resistência, esse esforço de negação e repulsa que o homem tem perante o mimetismo de que vive. Que logo a primeira tese de Girard concede muito pouca possibilidade de autonomia ao homem, esse comportamento de "plantar" flores artificiais seria para Girard mimético de imitar a Natureza, mas principalmente mimético de ser apontado ao impressionar / ultrapassar o outro, com flores naturais (ou mesmo já artificiais) no seu quarto, posto como modelo a imitar.

${ }^{26}$ em Bacon, Novum Organum, I, 129.

27 Já bem Platão (Leis, IX, 855c), recomenda uma infamante exposição dos delinquentes nas fronteiras.

${ }^{28}$ É custoso aceitar-se a postura de Hadot de que a ciência e o racionalismo deram fim às representações personalizadas da natureza (p.337). E se a personalização se aproxima de um querer dizer "sacralização" então é inaceitável. Mais que conservar, a ciência sobrevive do mito. Logo na sua linguagem, naquelas fórmulas de símbolos incompreensíveis, na molécula do ADN "feita" essência da vida, na "partícula de Deus", "descoberta" pelo acelerador de partículas (excitações que o conhecimento das antinomias kantianas da razão poderiam refrear). Logo no quotidiano (des)encantado que a ciência nos forneceu onde a representação mágica é substituída pela fé do cidadão numa ciência e técnica desconhecidas. Já Webber via no homem moderno entre objectos e mecanismos desconhecidos um homem primitivo no seu mundo mágico (DUPUY, 2008, p. 73, de Webber, Le Savant et le Politique, Librarie Plon, 1959, pp 69-70). A ciência, querendo fundar-se de todo na razão e negar o sagrado, sacraliza. Hoje a ciência segue mesmo um projecto demiúrgico de manipular a matéria à escala atómica apontado a um futuro messianizado patente no programa Converging Technologies for Improving Human Performance (o NIBC, que visa a convergência a entre as tecnologias nano, info, bio e cogni), ou no nano2life, (bringing nanotechnology to life, (DUPUY, 2008, p. 84)). Um clássico monismo de substância primordial e universal regula nos mesmos princípios natureza, vida e espírito numa forçada naturalização, ou mecanização que tomando forma de algoritmo informacional se estende a universal modelo $e$ legislador. Faz-se então da vida algoritmo info-genético que, desvelado, permitirá uma futura bio-fabricação (DUPUY, 2008, pp. 89,90). Embora, na representação do real em figura radial de informatizada informação, o

Problemata: R. Intern. Fil. v.6, n. 3(2015), p 283-319 ISSN 2236-8612 
materialismo monista já derrape a espiritualizar-se, não deixa de prometer ao homem o making life from scratch, o lema da biologia sintéctica, (re)solvendo, todas as alienantes distinções entre animado, inanimado, artificial, (DUPUY, 2008, pp. 97,98,102,103). O velho futuro messiânico, então, em lista de promessas resolventes. A transferência de personalidade e memórias a um wetware biosintetizado para receber sucessivos upgrades resolve o problema da morte (DUPUY, 2008, p.105,6). Um grande e único cérebro em interconectação radial resolverá todos os demais problemas acrescentando surpreendentes benefícios. Entre uma lista numerosa, destaque-se a paz e bem-estar universais, a energia ilimitada e o fim dos problemas ambientais, ((DUPUY, 2008, p.113), regressa-se à New Atlantis de Francis Bacon: "The End of our Foundation is the knowledge of Causes, and secret motions of things, and the enlarging of the bounds of Human Empire, to the effecting of all things possible».

${ }^{29}$ Está aliás muito próxima da tese de André Orléan (1982) que, para além de apontar a moeda, e assim o dito sistema capitalista como sacrificial, canalizador cada vez mais imperfeito da violência, trata das violentas consequências duma teoria económica clássica que, assente no mito do agente económico autónomo, liberal e racional, não quer ver os elementos esmagadoramente miméticos nos padrões de consumo (que a publicidade e o marketing tão bem exploram) ou do comportamento dos investidores em mercado financeiro.

${ }^{30}$ Girard, contrariamente ao dogma dominante do comércio pacificador dos povos, concorda com Clausewitz descobrindo no comércio uma estrutura de duelo, camufladora duma guerreira, e assim perigosa (até por seus efeitos miméticos), concorrência (GIRARD; 2007, pp.114-118).

${ }^{31}$ Já se defendeu que esta queda da natureza a coisa tem talvez passos mais profundos e modestos, franciscanos até. Relativamente a Rousseau, acrescente-se aqui a sua intuição do carácter violento da nossa natureza mimética (DUPUY, 2005, pp. 62-64). No princípio, (por exemplo em Essay sur l'origine des langues) os homens dispersos, viviam em bucólica primitividade, livres e livrados de trabalhos e miséria. Até o homem se tornar social e criar as artes, as leis, o comércio, as cidades, até o homem criar aquele estado de natureza hobbesiano: «je vois les hommes, rassemblés sur quelques points de leur demeure pour s'y dévorer mutuellement, faire un affreux désert du reste du monde, digne monument de l'union sociale et de l'utilité des arts». A passagem de um estado a outro, é a passagem do amor de si (todo bondade e piedade, onde cada um é seu espectador e juiz no Discours sur l'origine et les fondements de l'inégalité parmi les hommes) ao amor próprio onde o mal vem da comparação, da inveja, pode arriscar-se do desejo mimético de possuir o outro: "Quand (...) les hommes commencent à jeter les yeux sur leurs semblables (...) leurs intérêts se croisent (...), l'amour de soi mis en fermentation devient amour-propre» (Lettre à Beaumont).

${ }^{32}$ Aliás o imitar a natureza não se confina ao social; é parte integrante da técnica: o automatismo quer imitar a natureza, apoderar-se de sua autonomia.

${ }^{33} \mathrm{Sim}$, ela não responde, como reza a fórmula de ridicularizar Michel Serres e seu Contrat Naturel (1990). Não responde como qualquer rival, mas nós não deixamos de significar, personificando, suas respostas; para nós ela

Problemata: R. Intern. Fil. v.6, n. 3(2015), p 283-319 ISSN 2236-8612 
ainda responde, e se vinga, como em grande parte dos discursos ambientais; ela, em muito discurso científico remanescente de paradigmas que se querem acreditar ultrapassados, é força, quando não ameaça, que o homem deve dominar ou pelo menos força da qual o homem se deve libertar.

${ }^{34}$ Moscovici, p.15.

${ }^{35}$ A postura órfica que lhe é atribuída por Hadot não se isenta também assim de reflexos prometaicos. Não é de estranhar. A viragem para o progresso é prometaica mas o caracter sacrificial do mesmo é retorno órfico. Como a atitude órfica, a atitude prometaica extremada é também sacrificial, preserva em seu funcionamento o mecanismo em forma adulterada.

${ }^{36}$ Moscovici, p. 17. Todavia, acerca disto já se tratou do usus pauper franciscano.

${ }^{37}$ Moscovici, p. 18.

${ }^{38}$ Aliás, Rousseau, para Moscovici, o principal embora talvez involuntário despoletador desta atitude perante a Natureza que, na passagem do amor de si ao amor próprio, intui, como vimos, a nossa natureza mimética, assistiu uma vez horrorizado à manifestação desta segunda natureza sacrificial do homem, à materialização em carne e osso, fora da sua asséptica intelectualização, dessa vontade geral unificadora fundada na negação, extremada no ódio geral unânime. Para Michel Serres (1980), o fim do livro XII em Les Confessions, o fim de Les Confessions, descreve esse Rousseau chocado de se ver constituir contra si uma união que, unânime, o tenta delapidar, «spectacle de la haine du peuple».

39 O caminho da igualização pelo cristianismo está também na própria ciência que possibilita. Para além do forçar a natureza a tornar-se útil ao homem, "humanizada", a igualização segue na própria acção quantificadora, formal e formular da ciência permitindo comparar $e$ relacionar o antes incomparável e irrelacionável. Aliás, os primórdios da revolução mecanicista já democratizam um saber que, contra autoridades livrescas, faz da natureza livro em caracteres matemáticos universais (Galileu), propondo um método aberto a todos (Bacon e Descartes), promovendo a investigação conjunta retira o monopólio a isolados sábios e iniciados (HADOT, pp.145,146,148). Diga-se também que a própria verdade científica nasce ainda do mainstream, acabada quantificação de votos entre os qualificados na matéria; o científico faz-se do que uma maioria da comunidade científica, ou a corrente dominante, declara, para já, como científico.

${ }^{40}$ A natureza «nos quis preservar da ciência, como uma mãe arranca uma arma perigosa das mãos de seu filho» (HADOT, p. 315), ou, acrescente-se, como uma mãe neolítica que mantém o seu filho no colo junto a seu peito, o natural e nutridor mecanismo.

${ }^{41}$ Lenoble, p. 199.

${ }^{42}$ Este esquema é facilmente aproximável ao esquema cíclico pagão do bode expiatório eterno (re)fundador de nova cultura, ou natureza.

${ }^{43}$ Diga-se a propósito que também pela via da propagação da "mentira romântica", da insistência na diferença e na liberdade, o mito do homem autónomo e nunca mimético (supostamente oposto ao mecânico) contribui para camuflar a natureza mimética do homem, para Girard, a verdade romanesca.

Problemata: R. Intern. Fil. v.6, n. 3(2015), p 283-319 ISSN 2236-8612 
${ }^{44}$ Esta natureza "misteriosa em pleno dia" de Goethe ("respeita o mistério (...) a natureza-esfinge, coisa monstruosa, te aterrorizará com seus inumeráveis seios» (HADOT, p.311)), cujo véu é não ter véu, não deixa de concordar com a transparente unanimidade do todos contra um (sendo que este se convence também de sua culpabilidade), assim escondida por não a sabermos ver com os nossos olhos, bom indício de funcionamento saudável, natural, do mecanismo até à revelação (Hadot, p.169). O mesmo para o mimetismo tão descarado das relações humanas que a mentira romântica se esforça por negar.

${ }^{45}$ Sempre um homem, sempre um jovem a levantar o véu da Deusa (a violála), nunca uma mulher, uma jovem. Mantém-se o cânone mitológico.

${ }^{46}$ de NIETZSCHE, Para lá do bem e mal, 59.

47 Os avisos antigos contra o mover das profundezas da terra, contra a violação incestuosa da mãe natureza, encontram aqui uma mais profunda formalização. Carrega-se no interdito dessa penetração desfloradora, reveladora da Natureza e assim comprometedora desse terrível mecanismo na natureza humana.

${ }^{48}$ Crepúsculo dos Ídolos, 49.

${ }^{49}$ Reesclareça-se aqui que, em Girard, tudo o que directa ou indirectamente, consciente ou inconscientemente negue ou ignore tanto o mimetismo essencial como o mecanismo do bode expiatório tende a ser sacrificado à categoria de sacrificial. Que toda a cultura pré-cristã é sacrificial e a póscristã contém ainda muitos elementos sacrificiais, Girard faz-se península, rodeia-se do sacrificial por todos os lados menos por um, a tradição bíblica, particularmente a cristã.

${ }^{50}$ E esta distância vai diminuindo progressivamente de Emma Bovary (tendo como modelo as heroínas românticas das suas leituras) a Julien Sorel (Le Rouge et le Noir onde a reacção negra vence por se igualizar ao vermelho revolucionário) até se tornar igualizante nas personagens snobs que pululam La Recherche de Proust, e em algumas obras de Dostoievsky como Os Cadernos do Subterrâneo ou particularmente na personagem Stavroguine a merecer o superlativo hebraico de possesso d'Os Possessos. Esta galopante preponderância dos modelos internos reafecte para Girard um evoluir histórico real.

${ }^{51}$ Principalmente desenvolvida em La Violence et le Sacré (1972).

${ }^{52}$ A concepção de sagrado em Girard, aceitando a tradicional ambivalência que o pensamento religioso e antropológico lhe dá, inclui o estafado exemplo de Frazer: esse sagrado, esse fogo que a uma certa distância aquece e pode ser aproveitado mas muito próximo queima, incluindo já esse contágio que convém controlar, é, seguindo nessa indeterminação com atributos contraditórios, directamente identificado por Girard a essa violência que uma sociedade, podendo moderadamente usar, tem de controlar com mecanismos de contenção e expulsão.

${ }^{53}$ Marca do sagrado que, aos olhos da comunidade, torna a vítima boa condutora da violência. Embora arbitrária, a vítima a escolher não deixa de apresentar determinadas propriedades. Em primeiro lugar, a vítima não deve ser susceptivel de ser vingada para melhor se interromper a cadeia mimética da violência. Deve então depois apresentar esses inais sacrificiais, diferenciadores mas perfeitamente arbitrários também, que a tornam

Problemata: R. Intern. Fil. v.6, n. 3(2015), p 283-319 ISSN 2236-8612 
potencial bode expiatório. Ou defeito físico (ainda hoje o bullying nas escolas às crianças obesas une as crianças perseguidoras),ou pertencer a um grupo étnico já de si marginalizado, por ser estrangeira. O importante é que nem esteja demasiado inserida, nem demasiado fora da comunidade; esteja à margem, concorde com essa ambiguidade, marginalidade do sagrado. É o caso do rei a sacrificar que é necessário exteriorizar (o rei tende a ser isolado da comunidade, pode transgredir interditos comuns e tem interditos especiais, por exemplo, nalgumas tribos não pode tocar o chão) e do prisioneiro de guerra a sacrificar que deve ser interiorizado (vive quotidianamente durante determinado período como se fosse um elemento do grupo).

54 Obtém-se assim resultado similar ao da vítima expiatória não vingável.

${ }^{55}$ Principalmente desenvolvida em Le Bouc Émissaire (1982) e Les Origines de la Culture (2004).

56 Com contraponto na clássica figura mitológica clássica dos gémeos violentos (que representarão essa igualização violenta em crise sacrificial: daí os tabus generalizados não só contra eles mas também, em bom mimetismo mágico associativo, contra as parecenças podendo incluir-se também aqui a matrilinearidade afastadora de pai e filho em muitas culturas) onde, em exemplo mais óbvio, o assassinato de Remo por Rómulo (cuja camuflada morte posterior também se reveste de marca vitimária) é descrito em tom favorável pelo mito.

${ }_{57}$ Por exemplo, Lc 11, 47-49.

${ }^{58}$ Também assim Girard pretende responder à antropologia do século XIX obcecada em desacreditar o cristianismo na exposição de suas semelhanças míticas com outras religiões. As semelhanças estão lá propositadamente, só falando mítica e religiosamente se pode fazer uma desmitificação antisacrificial, inverter para a o ponto de vista da vítima inocente.

${ }^{59}$ Principalmente desenvolvida em Achever Clausewitz. (2007).

60 Oughourlian, em Psychopolitique (2010), trata de "mimeticamente" refutar o "choque de civilizações". Os árabes tão igualizados a Coca-Cola, calças levy's e Hollywood a seus modelos americanos não lhes podem perdoar preferências judaicas. O discurso da diferença religiosa e cultural é esforço de negação desse rival já muito igualizado a seu rival / modelo.

Problemata: R. Intern. Fil. v.6, n. 3(2015), p 283-319 ISSN 2236-8612 